$\frac{39}{3}-28,45$ us lat \# $\%$ l

$I-20199$

D. $0902-4$

Orinl/cso/Th-225

MARTIN MARHETTA

\title{
Review of PGDP Assessment of Criticality Safety Problems in Increasing Product Assay to 5 wt $\%{ }^{235} \boldsymbol{U}$
}

\author{
L. M. Petrie \\ J. C. Turner \\ G. B. Stewart
}


ORNL, CSD/TH--225

o.

DE85 008765

COMPUTING AND TELECOMMUNICATIONS DIVISION at

Oat Ridige Nutional Laboratory

Post Office Box $X$

Mak Ridge, Tenaessee 37830

Review of PGDP Assessment of

Criticality Safety Problems in Increasing Product Assay to 5 wt $\%{ }^{235} \mathrm{U}$

L. M. Petrie

J. C. Turwer

G. B. Stewart

Manuscript Completed: Norcmber 1984 Date Publisted: Fetruary 1985

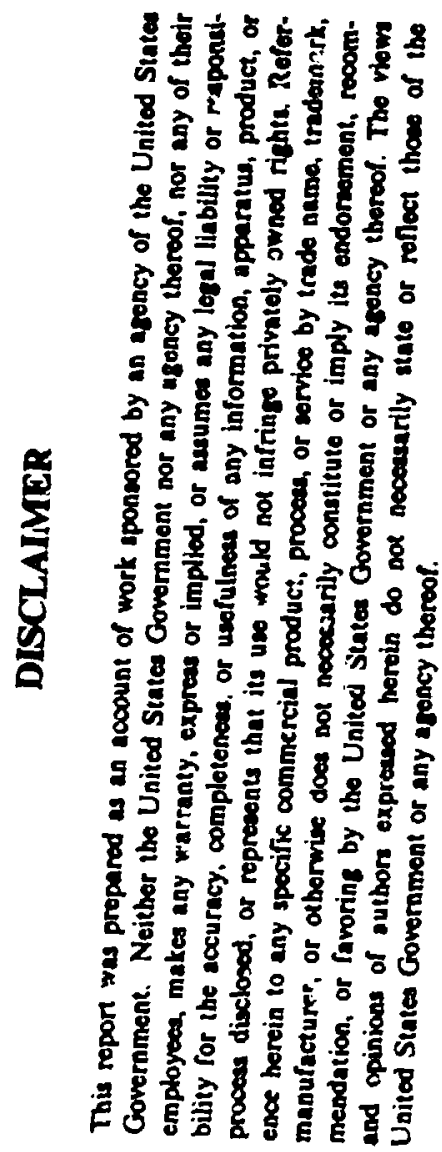

Martin Marietta Energy Systems, Inc. operating the

Onk Ridge National laboratory Oak Ridge Y-1? Plant

Oak Ridge Gaseous Diffusion Plant Paducah Gaseres Diffusion Plant

unoer Contract No. DE-ACOS-840R2 4400

for the

DEPARTMENT OF ENERCY $Y$ 


\section{CONTENTS}

LIST OF FIGURES

LIST OF TABLES

vii

ACKNi)WLEDGEMENTS

ix

ABSTRACT

xi

INTRODUCTION

BASIC CRITERIA FOR DETERMINING NUCLEAR SAFETY

NUCLEAR SAFETY CONSIDERATIONS IN CASCADE EQUIPMENT

Surge Drums

Uranium Hexafluoride Freezer/Sublimer

Product Cylinders

Spacing Considerations 'or Storage of Product Cylinders

Accumulators

UFo/R-114 Separator System

Sodium Fluoride Traps

Alumina Traps

Magnesium Fluoride :raps

Pump Oil Separators

C. 310 Scale Pits

Storage of Contaminated Waste

NUCLEAR SAFETY CONSIDERATIONS IN DECONTAMINATION AND RECOVERY EQUIPMENT

Spray Booth and Associaled Storage Tarks 9

Small Parts Hand Decontamination Table

9

Cortaminated Solution Acidifying and Storage ?anks

Uranium Precipitation Svstem

Cylinder Wash Facility

NUCLEAR SAFETY CONSIDERATIONS IN THE C-360 SAMPLING COMPLEX

Autoclaves

Various Tanks

Alumina and Cold Traps

Scale and Elevator Pits

Oil Interceptors

CRITICALITY ALARM SYSTEM

CONCLUSIONS

Nuclearly Safe as Now Exist

Nuclearly Safe with Additional Administrative Controls

Nuclcarly Safe with Modifications to Existing Eyuipment

Nuclearly Safe Only if Replaced with New Fquipment 


\section{LIST OF FIGURES}

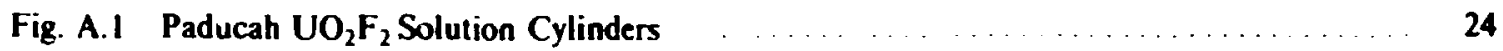

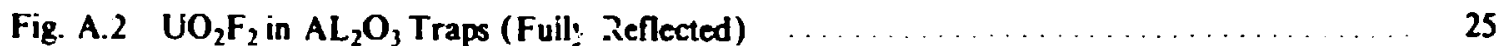

Fig. A.3 Product Accumulators (Fully Reflected) $4.5 \%$ vs. $5.0 \% \quad \ldots \ldots \ldots \ldots \ldots \ldots \ldots$

Fig. $\lambda .4$ Optimum U Concentration for NaF Burp Traps $\ldots \ldots \ldots \ldots \ldots \ldots \ldots \ldots \ldots \ldots$ 


\section{LIST OF TABLES}

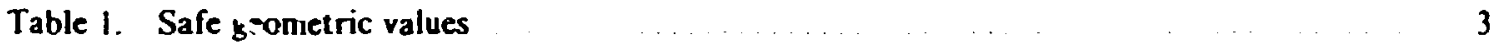

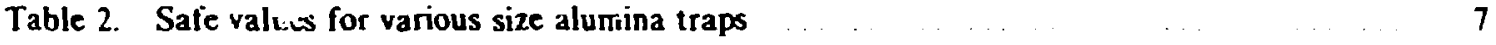

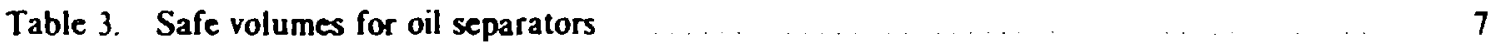

Table 4. Minimum quantities required for criticality in C-360 pits 12

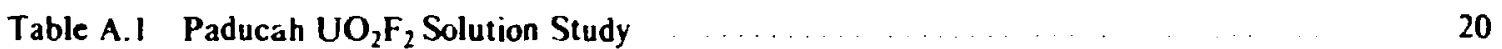




\section{ACKNOWLEDGEMENTS}

The authors gratefully acknowledge the thorough review and many helpful comments supplied by Mr. R. C. Baker, Mr. Carl W. Walter, and their Review Committee.

The authors also appreciate the assistance of Lindy Norris, who patiently drafted and redrafted tinis report and corrected numerous formatting and spelling errors. 


\begin{abstract}
Paducuh Gaseous Diffusion Plant (PGDP) performed an evaluation of the PGDP facilities to deternine the feasibility of inc:casing product assay from $2.0 \mathrm{wt} \%$ to $5.0 \mathrm{wt} \%{ }^{235} \mathrm{U}$ and to determine the impact of this increase on plant criticality safety, their conclusions are reported in KY-710. This report critiques the methods used and conclusions reached in KY-710.
\end{abstract}




\section{INTRODUCTION}

In Algust 1983 the Paducah Gaseous Diffusion Plant (PGDP) asked the Nuclear Engineering Applications Depariment, Computing and Telocommunications Division, to review a report, KY-710, on the criticality safely considerations of increasing the product assay from 2.0 wt $\%$ to 5.0 wt ${ }^{233} \mathrm{U}$. Com, iter analyses were to be used to verify that appropriate criteria had been applied in arriving at the conclusions presented in the report and to analyze the suggested modifications for achieving criticality safety in the Paducah operations. The analyses are summarized in Appendix $A$.

The report being reviewed, KY-710, noted that it did not constitute formal nuclear safety arproval of the proposed methods of modification. Likewise, this review is for the purpose of providing guidance in long-range planning and does not constitute a formal safety approval of the individual process systems. Resp insibility for the formal approval remains in the PGDP organization.

This review is organized as comments on the corresponding sections of KY-710. For completeness some tables from KY-710 have been copied and included; other sections oi KY-710 have been liberally paraphrased to give a background or explanation for the corresponding comments. 


\section{BASIC CRITERIA FOR DETERMINING NUCLEAR SAFETY}

KY-710 set forth the following seven criteria for determining nuclear safety:

1. Uranium hexafluoride in the gaseous phase, as encountered at temperatures, pressures, and compositions typical of a diffusion casc-de, cannot sustain a nuclear chain reaction. Gaseous UF $_{6}$ is, therefore, always nuclearly safe regardless of whether the assay is 2 wt $\%$ or 5 wt ${ }^{235} U$.

2. Uranium enriched', not greater than $5.0 \mathrm{wt} \%{ }^{235} \mathrm{U}$ cannot sustain a nuclear chain reaction in the absence of moderating atoms such as hydrogen $(\mathrm{H} / \mathrm{U}$ ratio $\leqslant 0.33)$.

3. At $5 \%$, the minimum theoretical critic 1 mass is approximately $81 \mathrm{lb}$ of uranium ( $120 \mathrm{lb}$ of $\mathrm{UF}_{6}$ ). At $2 \%$, the minimum critical mass is more than six times larger $-506 \mathrm{lb}$ of uranium $(748 \mathrm{lb}$ of $\left.U F_{6}\right)$.

a. For criticality saiety purposes if double-batching* is not possible, the safe mass is set at $90 \%$ of the minimum critical mass (safeiy factor - 1.25). This corresponds to $65 \mathrm{lb}$ of uranium enrichid to 5 wt $\%{ }^{235} \mathrm{U}$.

b. If double-batching is not precluded, the sate mass for $5 \%$ cnrichment would be $35.3 \mathrm{lb}$, allowing a safety factor of 2.3. This safety factor would allow for two containers to be combined and still be nuclearly safe.

4. Table I summarizes the safe geometries at both 2 wt $\%$ and 5 wt $\%{ }^{235} U$. Because gei try control requires no administrative controls to be effective, it is the most positive form of . Lear safety control; implementation of this method should be considered wherever possible.

Table 1. Safe geometric values

\begin{tabular}{lrccc}
\hline \multicolumn{1}{c}{ Geometry } & $2 \%$ & $5 \%$ & Safety Factor \\
\hline a. Infinite slab depth (in.) & 8.7 & 5.0 & 1.05 \\
b. Infinite cylinder diameter (in.) & 16.0 & 10.25 & 1.05 \\
c. Volume (gal) & 25.1 & 7.1 & 1.1 \\
\hline
\end{tabular}

5. Al : : : wianium enrichment, the safe concentration of ${ }^{235} \mathrm{U}$ in a water solution is 5 grams per liter with a safety factor of 1.9. Tor $S \%$ arsay, this corresponds to a concentration of 100 grams of uranium per liter. At $2 \%$, the safe concentration is 250 grams of uranium per liter of solution.

6. It is impossible for uranium enricised $t$, less than 1 wt $\%{ }^{235} U$ to bejome critical under accident conditions.

7. Spacing considerations for containers are based upon a total solid a:igle of interaction equal to 1 steradian for safe geometry containers. For safe masses, the permissible total solid angle of interaction is equal to 2.5 steradians. In general, the spacing provided for the $2 \%$ system will be adequate for $5 \%$ systems when the control used to maintain criticality safety is the same.

These are standard, commonly accepted criteria in use in the nuclear industry. An eighth criterion could be added requiring a system analysis using a validated computer code and cross sections to show the system is subcritical. The margin of subcriticality needed to be safe using this criteria depends on the validation results of the code and cross sections.

- Double-batching iefers to the possibility of accidentally doubling the mass of uranium in one container (c.g., two half-fill, 55-gal drums are combined). 


\section{NUCLEAR SAFETY CONSIDERATIONS IN CASCADE EQUIPMISNT}

Criterion I states that all cascade equipment which processes only gaseous phase UF 6 is always nuclearly safe under normal operating conditions regardless of whether the assay is 2 wh $\%$ or 5 wt $\%{ }^{235} \mathrm{U}$. This review was requested by PGDP to address this point; and certainly at normal operating conditions, i.e., UF 6 in the gaseous phase, Criterion $\mathbf{l}$ is both applicable and ralid.

For abnormal conditions, as long as the level of internal moderation is limited, both Criterion 2 and a computer analysis show the equipment will still be safe. However, if sufficient moderation is introduced into the equipment during an accident and, if sufficient $U_{6}$ has also accumulated in toe same location due to freeze-out, then these criteria are no longer applicable. At optimum moderation, the geometric configuration is such that several hundred pounds of UF, are required before the safe geometry criterion is violated.

\section{Surge Drums}

To be nuclearly safe by Criterion I the surge drums must be operated at a temperature and pressure combination which does not allow the stored $U F_{6}$ to condense. If condensed $U_{F}$ is to be stored, regardless of the assay of the uranium, three parameters must be controlled: the weight of the condensing $U_{6}$; the pressure in the drum, to maintain structural integrity, and the hydrogen content, to preclude the availability of a moderator (Criterion 2).

For safe condensation the weight limitation of $4.5 \%$ enrichment is satisfactory based on the current limitation of product cylinders. However, due to the discrete sizes of the cylinders, KY-710 includes a large weight differential (from 15,000 down to $5,000 \mathrm{lb}$ ) in going from 4.5 to $5.0 \mathrm{wt} \%$ enrichment. If the $5,000-1 b$ limit at $5 \%$ causes no operational problems, it is surely conservative. If necessary, the $15,000-\mathrm{lb}$ limit could probably be justified at $5 \%$ as well as at $4.5 \%$.

Overall, the surge drum analysis presented in $\mathrm{KY}-710$ appears quite conservative.

\section{Uranium Hexafuoride Freezer/Sublimer}

The freezer/sublimer system has already been evaluated and approved as critically safe for enrichments up to 5 wt $\%{ }^{235} \mathrm{U}$. An overview of this system is given here, but a more detailed study is given in $K Y-710$.

The purpose of the UF 6 freezer/sublimer is to reestablish stable cascade operating conditions in the event of a disturbance causing an excess of uranium. This system consists of a shell which encloses a lattice of finned tubes containing water-cooled refrigerant-114. With this design, excess UF $_{6}$ from the cascade can be either frozen around the tubes in the shell side of the vessel or sublimed to the gascous state for gradual return to the cascade. One safety feature of the freezer/sublimer maintains appropriate temperatures and pressures to assure that HF present in ti,e cascade stream cannot conciense as the $\mathrm{UF}_{6}$ freezes out, thus eliminating $\mathrm{HF}$ as a source of moderation. Other safety designs monitor differential pressure to protect against the leakage of water into the R-114 loop, allowing moderation of uranium in the shell side of the vessel. If, in spite of these safety features, full density water does enter the tube side of the freezer/sublimer, accidental criticality is still not possible if the assay of the UF being processed is beiow $2.35 \%$. 


\section{Prodect Cyitimeders}

Product cylinders of four different sizes were teviewed in KY-710. The 14-ton and 10-ton cylinders are both nuclearly safe for storage of uranium with $4.5 \%$ assay. The $21 / 2$-ton cylinders and MDcylinders can safely store uranium enriched to $5 \%$. National Standard, ANSI N14.1 1982, covers the limitations on the 48 -in.-diameter product cylinders at $4.5 \%$ enrichment.

\section{Spacing Considerations for Storage of Product Cylmedes}

The present spacing regulations requiring a 1-ft, edge-to-edge separation of cylinders should be sufficient with the $4.5 \%$ and $5 \%$ product cylinders. No further restrictions are anticipated.

\section{Acemomators}

The product accumulator resembles a 10-ton product cylinder and has a storage capacity of 21,000 lbs. The KY-710 analysis conseivatively concluded that this accumulator would be nuclearly safe up to $4.5 \%{ }^{235} \mathrm{U}$ but would need to be replaced if the assay were increased to $5 \mathrm{wt} \%{ }^{235} \mathrm{U}$. Since accumulators are not transport containers and are not restricted by a national standard, a careful analysis of these accumulators should show them safe at $5 \%$ provided the moderation control of Criterion 2 is met. See Appendix A for further discussion of this point.

The side withdrawal accumulator, $4360-1 b$ capacity, would be safe at $5 \%$ enrichment with moderation control for the $21 / 2$-ton cyinder applied.

\section{$U_{6} / R-114$ Separator System}

In a previous analysis the $U F_{6} / R-114$ separator system was found nuclearly safe at assays not greater than 2 wt $\%^{235} U$. Based on this analysis, PGDP decided that the separator system will be restricted to assays of less than $2 \%$. If it becomes necessary to use this system for processing uranium at greater assays, a smaller diameter vessel will have to be designed and evaluated.

\section{Sodium Fluoride Traps}

None of the six sodium fluoride traps currently in use at PGDP are nuclearly safe for assays of 5\%. The two traps located in C-335 are used to trap residual UF 6 from the UF 6 /R-114 separator system. As long as the $U_{6} / R-114$ separator is restricted to assays of less than $2 \%$, these traps will not require modification. Shouid the UF $6 / R-114$ separator be modified to handl= larger assays, these two traps will need to be modified also.

The other four traps, located in C-310, are used in conjunction with the cylinder burp" stations and must handle $5 \%$ assay material. Analysis of these traps (see Appendix A) shows they are not subcritical unless moderation control can be implemen:ed. Since reducing the trap's volume to limit the amount of $\mathrm{UF}_{6}$ which may be trapped out is probably not feasible, these traps will need to be replaced.

\section{Alumina Traps}

The following table reproduced $\therefore \mathrm{m}$ KY-710 presents safe values for various size alumina traps based on different criteria. 
Table 2. Safe values for various size alumina traps

\begin{tabular}{ccccc}
$\begin{array}{c}\text { Diameter } \\
\text { (in.) }\end{array}$ & $\begin{array}{c}\text { Volume } \\
\left(\mathrm{ft}^{3}\right)\end{array}$ & $\begin{array}{c}\text { Mass of } \\
\text { U Trapped } \\
\text { (lb) }\end{array}$ & $\begin{array}{c}\text { Safe Assay } \\
\text { by Geometry } \\
\left(w^{2} \text { \% }^{235} \mathrm{U}\right)\end{array}$ & $\begin{array}{c}\text { Safe Assay } \\
\text { by Mass } \\
\left(w^{2} \text { q }^{235} \mathrm{U}\right)\end{array}$ \\
\hline $10.25 *$ & NR** & NR** & 5.00 & NA \\
12.00 & 1.7 & 64 & 3.50 & 5.00 \\
15.00 & 3.7 & 137 & 2.25 & 3.25 \\
18.00 & 8.0 & 298 & 1.65 & 2.15 \\
24.00 & 13.2 & 190 & 1.25 & 1.80 \\
\hline
\end{tabular}

- This size trap is not currently present in the cascade. It is listod for comparison - should Method I of the preceding discussion be chosen.

* No restriction.

Cumputer analysis indicates that the safe arsay by mass results are somewhat conservative. For instance, the 15-in. trap will be safe with $4 \%$ (rather than the $3.25 \%$ given in the table) assay material under the conditions of the safe assay by mass. See Figure A.2 in Appendix A.

When deciding whether to use the "safe assay by genmetry" or the "safe assay by mass" method to determine criticality safety, a word of caution is in order. If the "safe by mass" method is chosen, strict administrative controls will be necessary to ensure that no more than the proper amoust of trafping material is present.

\section{Magnesium Fluoride Traps}

There are two magnesium fluoride traps in $\mathrm{C}-310$ which will need to be nuclearly safe for assays up to $5 \mathrm{wt} \%{ }^{235} \mathrm{U}$. As the current traps do not meet this requirement, the cenclusion of KY-710 that these traps need to be modified or replaced is correct.

\section{Pump Oil Ser arators}

The analysis and table (see below) presented in KY-710 for the pump oil separators provide an idequate basis for deciding which separators are safe and which need to be replaced when the final piant assay is $5 \%$. However, the assessment indicates that hydrocarbon oil can accumulate a maximum of $4.5 \mathrm{lb}$ of $\mathrm{UF}_{6}(3.04 \mathrm{lb} \mathrm{U})$ per gallon of oil. This uranium concentration is less than the optimum value for $5 \%$ material. Thus, this maximum possible value is more dilute and on the overmoderated side of the optimum. Hence, the safe masses listed in the tabie for a given assay could be increased while increasing the safe oil volume proportionately.

Table 3. Safe volumes for oil separaturs

\begin{tabular}{|c|c|c|}
\hline $\begin{array}{c}\text { Assay } \\
\left(\mathrm{Nt} \text { \% }^{235} \mathrm{U}\right)\end{array}$ & $\begin{array}{c}\text { Safe Mass* } \\
\text { (lb of U) }\end{array}$ & $\begin{array}{c}\text { Safe Oil } \\
\text { Volume } \\
\text { (gal) }\end{array}$ \\
\hline 1.00 & $N R^{* *}$ & NR** \\
\hline 2.00 & 405 & 133 \\
\hline 3.00 & 162 & 53 \\
\hline 3.5 & 122 & 40 \\
\hline 4.00 & 95 & 31 \\
\hline 5.00 & 65 & $21^{\circ}$ \\
\hline
\end{tabular}

-Double-hatchin;; prezluded.

*No restriction. 


\section{C-310 Scale Pits}

The C-310 scale pits have close-off valves which will shut the drain line to the cylinder when a leak is detected, and a system to slose the cylinder valire upon UF, detection is scheduled for installation. Additionally, the use of water on any enriched uranium release is administratively controlled, and criticality at assays belor, $5 \%$ is not possible in the absence of a moderatci. The $Y-1-710$ analysis of the C-310 scale pits is toth correct and adequate in its conclusion that this combination of safety features virtually nullifies the puiential for criticality.

\section{Storage of Contaminated Waste}

Two options for nuclearly safe storage of contaminated wastes are presented in KY-710. One option is to purchase special containers with an inner diameter of no more than $10 \mathrm{in}$; the second option is to use 5-gallon buckets. As long as strict rules governing the spacing between columns of storage containers are followed, either sption is both safe and feasible. 


\section{$9 / 10$ \\ NUCLEAR SAFETY CONSIDERATIONS : N DECONTAMINATION AND RECOVERY EQUIPMENT}

Located in $\mathrm{C}-400$, the decontamination and recovery facilities handle equipment from all areas of the plant; they are, therefore, required to be nuclearly safe for the top assay which may be encountered $-5 \mathrm{wt} \%{ }^{235} \mathrm{U}$.

The follcwing systems within the decontamination and recovery facility possess a potential for criticality: the spray booth and associated storage tanks, the small parts hand decontamination table, the contaminated solution acidifying and storage tanks, the uranium precipitation system, and the cylinder wash faciity. Each of these systems is addressed separately.

\section{Spray Booth and Associated Storag- Tauks}

With the exception of the storage tanks, all parts of the spray booth werr. Sound to be safe for decontaminating equipment exposed to $5 \mathrm{wt} \%{ }^{235} \mathrm{U}$. The alternatives for t.le storage tanks are to replace them with tanks that meet the geometry specifications of Criterion $4 \mathrm{~b} j \mathrm{~s}$ to make the current tanks nuclearly safe at higher assays by adding fixed neutron absorbers, such as Raschig rings. An evaluation using the KENO computer code showed the solution tan's to be sif; at assays of $5 \mathrm{wt} \%$ when poiscned with Raschig rings. See Appendix A for a discussion on this point.

\section{Sanall Paits Had Decontamination Table}

The decontamination table is usec for manually cleaning small parts which cannot be cleaned effectively in the spray booth. The conclusion of the KY-710 report that lowering the overflow level from 8.5 in. to 5 in. would make this table safe for $5 \%$ assays is correct and adequate.

\section{Contaminated Solution Acidifying and Storage Tanks}

The contaminated solution acidifying and storage tanks operate as two units of six tanks each five for storage and one for acidifying. All twelve tanks need to be nuclearly safe to handle assays at 5 wt \%. The alternatives are to replace all twelve tanks with 10.25-in. maximum diameter tanks or to use Raschig poison rings as neutron absorbers in the present tanks. A computer analysis was performed to verify that the addition of Raschig rings to the present tanks would make them nuclearly safe. Sec Appendix A.

\section{Uranium Precipitation Systea}

The uranium precipitation system is not nuclearly safe for uranium enriched to 5 wt $\%{ }^{23 s} U$. Either of the two alternatives presented in KY-710, isotopic dilution to less than 1\% of replacement of the system, would be a valid solution.

\section{Cylinder Wash Facility}

To prevent accidental criticality in the cylinder wash facility would require a combination of the following:

1. The drain pan would need overflow holes drilled at the 5-in. ievel.

2. The 16-in.-diameter storage tanks would need to be replaced with 10-in.-diameter tanks or would need the addition of neurror absorbers.

3. At $5 \%$ enrichment the cylinder heel weight would have to be limited to a maximum of $35 \mathrm{lbs}$. Because of the difficulty of accurately determining heel weights, additional safeguards' (either limiting the amount of wash solution in the cylinder or using a borated wash solution which has neutron absorbers) would be required. 


\section{NUCLEAR SAFETY CONSIDERATIONS IN THE C-360 SAMPLING COMPLEX}

The C-360 sampling cumplex works with liquid $\mathrm{UF}_{6}$, some of which is at product assay. Therefore, the whole facility must be safe at $5 \%$. The equipment requiring evaluation are the autoclaves, the various tanks, the traps, the scale and elevator, and the oil interceptors. Modifications necessary to ensure nuclear safety of each piece are considered individually.

\section{Autoclares}

Moderation control is the key to criticality safety for the autoclaves which are used for heating 10 and 14-ton cylinders of $4.5 \%$ and $21 / 2$-ton cylinders of $5 \%$ material. Normally, cylinder pressure is greater than the pressure of the autoclave; therefore, should a breach occur, UF 6 would be released into the interior of the autoclave but moderation could not enter the cylinder. A UF 6 detector is located in the autoclave, and when a leak is detected the following occur automatically.

1. The steam supply valve to the autoclave shuts.

2. The steam condensate drain line is rerouted to holding tanks.

3. If the autoclave becomes overpressured during the liquefaction mode, a rupture disk relieves the pressure so that $\mathrm{UF}_{6}$ containment is maintained.

Given these features, the limitations on the autoclaves are essentially the limitations of the product cyl- iders brought into the autoclave. Consequently, the autoclave will be safe at $4.5 \%$ with the 10 - and 14-ton cylinders and at $5 \%$ with the $21 / 2$-ton cylinders.

\section{Various Tanks}

The sampling and transfer facility has three sets of tanks. The surge tanks and the pressui $=$ relief tanks are currently safe for 5 wt $\%{ }^{235} \mathrm{U}$; KY-710 details the rationale for this conclusion. However, the 16-in.-diameter holdin tanks will need to be replaced with 10-in.-diameter holding tanks; or, the I6-in.-diameter tanks can : made safely subcritical with the addition of Raschig rings.

\section{Alumina and Cold Traps}

The alumina and cold traps are used in parallel with the surge evacuation tanks to achieve a better vacuum. Their diameters (less than 7 in. for the cold trap and less than 8 in. for the alumina) make both traps geometrically safe for $5 \%$ assay.

\section{Scale and Elerator Pits}

The four pits in C-360 which must be nuclearly safe are the first-floor scale pit, the basement scale pit, the hoist pit, and the elevitor pit. Table 4 , reproduced from KY-710, shows the minimum quantities of uranium and water necessary for criticality in each.

The possibility of accumulating the quantity of uranium necessary for criticality as a result of a gascous $U_{\mathrm{f}}$ release is very remote. KY-710 lists seven separate considerations which add to the nuclear safety of the pits. However, should further assurance of nuclear safety be required, iaschig rings can be placed in the pits as neutron absorbers. 
Table 4. Minimum quantities required for criticality in C-360 pits

\begin{tabular}{lccc}
\hline \multicolumn{1}{c}{ Pit } & $\begin{array}{c}\text { Volume* } \\
\left(\mathrm{ft}^{3}\right)\end{array}$ & $\begin{array}{c}\text { Uranium } \\
(\mathrm{lb})\end{array}$ & $\begin{array}{c}\text { Water } \\
(\mathrm{gal})\end{array}$ \\
\hline First-floor scale & 26.9 & 2,436 & 110 \\
Basement scale & 48.7 & 4,396 & 200 \\
Hoist & 49.8 & 4,511 & 204 \\
Elevator & 66.7 & 6,042 & 274 \\
\hline
\end{tabular}

*5-in. critical slab length.

\section{Oil Interceptors}

All floor drain lines in C-360 pass through two oil interceptors. When a release is detected in the building, valves in the influent lines automatically close. Should the valves malfunction, the first-floor separator would require $340 \mathrm{lb}$ of uranium to mix homogeneously with water before it was moderated to the correct degree for criticality. The other would require $115 \mathrm{lb}$. 


\section{CRITCALITY ALARM SYSTEM}

Based on the directive of DOE Manual Chapter 0530, Nuclear Criticality Safety, additional radiation alarms will probably need to be located in areas orocessing high assays. 


\section{CONCLUSHONS}

KY-710 presents a comprehensive evaluation of all of Paducah plant facilitiea with respect to nuclear safety during operation at a product as ; of 5 wt $\%{ }^{235} \mathrm{U}$. Computer analynes wae performed to verify the conclusions of the PGDP review. Below is a listing of the involved Paducah systems (reproduced from KY-710) organized into groups of nuclearly safe, need administrative controk, need modifications, and need to be replaced. At the end of each group are final comments on this review.

\section{Nuclearty Safe As Now Exist}

All equipment in which UF $_{6}$ is in gaseous phase (e.g., converters, compressors)

Surge drums up to $4.5 \%$

10- and 14-ton product cylinders up to $4.5 \%$

2\%-tor. and MD cylinders

Product accumulators up to $4.5 \%$

Side withdrawal accumulators

C-310 scale pits

Uranium hexafluoride freezer/sublimer

Spray booth (except solution storage tanks)

C-360 autoclaves

C-360 scale and elevator pits

C-360 oil interceptors

C- 360 surge and pressure relief tanks

Uranium precipitators (using isotopic dilution)

The KY-710 analyses for the surge drums and product accumulators were conservative. Computer analysis shows both to be nuclearly safe up to $5 \%$ as they now exist.

\section{Nuclearly Safe With Additional Administrative Controls}

Surge drums

$\mathrm{UF}_{6} / \mathrm{R} \cdot 1 / 4$ separator and associated $\mathrm{NaF}$ traps (restricted to $2 \%$ )

Alumina traps (some may be safe, depending on cascade gradient)

Pump oil separator (some may be safe, depending on cascade gradient)

Depending on the cascade gradient, some of the alumina traps and oil pump separators may need to be replaced. 


\section{Neclearty Safe With Modifications To Existieg Equipmeat}

\section{C-310 sodium !luoiide traps (possible)}

Magnesium fluoride traps (possible)

Storage of contaminated waste

Spray hooth solution storage tanks (addition of neutrcn absorbers)

Small parts hand decontamination table

Acidifying and storage tanks (addition of neutron absorbers)

Cylinder wash facility

Criticality alarm system

C-3ó0 steam condensate tanks (addition of neutron absorbers)

To be safe, the C-310 sodium fluoride traps and the magnesium fluoride traps will need to be replaced.

\section{Nuclearly Safe Only If Replaced With New Equipment}

Product accumulators (to enable handling $4.5 \%$ to $5 \%$ assay)

C-310 sodium fluoride traps (probable)

Magnesium fluoride traps (prohable)

Handling of contaminated traps (need safe diameter storage containers)

Finally, calculations of the 10-ton product accumulators show that with the required moderation control they are essentially as sale at $5 \%$ as at $4.5 \%$ assay. 
APPENDIX A

SUMMARY OF SUPPORTING ANALYSES

$17^{\prime}: 4$ 


\section{APPENDIX A}

\section{SUMMARY OF SUPPORTING ANALYSES}

As a starting point for later use in the study, the optimum concentration of $\mathrm{UO}_{2} \mathrm{~F}_{2}$ solutions for enrichments varying from $3 \mathrm{wt} \%{ }^{233} \mathrm{U}$ to $5.5 \mathrm{mt} \%{ }^{235} \mathrm{U}$ were determined. Using these concentrations. $k_{\text {efr }}$ as a function of cylinder radius for the different enrichments was calculated. These calculations were compared against standard criticality safety criteria and found to be compatible. The data generated from this study are given in Table A.l and displayed in Figure A.I.

Next, using the criteria given in KY-710 that the maximum weight of UF $_{6}$ absorbed on alumina is equal to the weight of the alumina, optimum concentrations of $\mathrm{UO}_{2} \mathrm{~F}_{2}$ solutions with alumina were determined, and maximum $k_{e j}$ 's for some of the alumina traps were determined as a function of enrichment. These cakculations were done by fixing the amount of $U$ in the trap, but allowing the distribution to change by varying the concentratio:. The remainder of the trap was then filled with an aluminawater mixture, and the trap was fully ri:flected. The results of this study are displayed in Figure A.2 and indicate that the values used in Table 2 of KY-710 are conservative and sould be relaxed somewhat if needed.

A study of the 10-ton product accumulator was performed next. Sirse this piece of equipment is similar to a 10-ton shipping cylinder which is approved for $4.5 \mathrm{wt} \%$ assay, this study was done at both $4.5 \%$ and $5 \%$. The results are displayed in Figure A.3. The first value on the figure (at $H / U<0.1)$ corresponds to assuming $0.5 \%$ impurity by weight, all $H F$. The middle point corresponds to assuming the $\mathbf{0 . 5 \%}$ is all $\mathrm{H}_{2} \mathrm{O}$, and the last point is the moderation limit specified in criterion 2. The c-iculation represents a 10-ton spherical mass fully retlected by water. As can be seen from the figure, $k_{e f}$ increases by about 0.025 in going from 4.5 to 5 wt $\%{ }^{235} \mathrm{U}$. Since the safety margin for this system is so large, this increase is not significant.

In order to study the $\mathrm{NaF}$ burp traps at 5 wt $\%$, tic optimum concentration of $\mathrm{UO}_{2} \mathrm{~F}_{2}$ and $\mathrm{NaF}$ was determined, assuming 2 lbs of UF per $\mathrm{lb}$ of N.F. These results are displayed in Figure A.4. Using this concentration, a 16-in.-diameter burp trap was analyzed including the monel heat transfer plates. The $k_{e n t}$ calculated was $1.031 \pm 0.003$. Unless the moderation can be cuntrolled, these traps will need to he replaced.

Finally, the effect of adding Raschig rings to an optimally moderated sulution was checked. Although only the single geometric configuration was considered, the $k$ infinity for the system was so far subcritical $(0.225)$ that any reasonable arrangement of Raschig rings will make any of the solution tanks subcritical. The systism studied corresponded to a close-packed, square nitched lattice of rings, so that about one-third the volume was occupied by glass. 
Table A.I Paducah UO, $F_{2}$ Solution Study

\section{$3.0 \times$ ELRICHED}

\begin{tabular}{|c|c|c|c|c|c|}
\hline \multicolumn{3}{|c|}{$\begin{array}{l}\text { INPHOMHEDIUH } \\
\text { CSASIX }\end{array}$} & \multicolumn{3}{|c|}{ INFINITE CILINDER } \\
\hline CASE & GU/L & INMBDA & CASE & RADIUS & LAMEDA \\
\hline P 3X1 & 3000 & 1.28646 & $\times 381$ & 15.7 & 0.952626 \\
\hline P 3X2 & 2500 & 1.31504 & $\times 382$ & 20.0 & 1.04305 \\
\hline P 3X3 & 2000 & 1.32379 & X3в3 & 18.0 & 1.00561 \\
\hline P3X4 & 1500 & 1.30249 & $\times 3$ B 4 & 13.0 & 0.873691 \\
\hline P $3 \times 5$ & 2100 & 1.32398 & & & \\
\hline P $3 \times 6$ & 2150 & 1.32367 & & & \\
\hline P 3X7 & 2050 & 1.32402 & & & \\
\hline
\end{tabular}

\section{$3.25 \times$ ENRICHED}

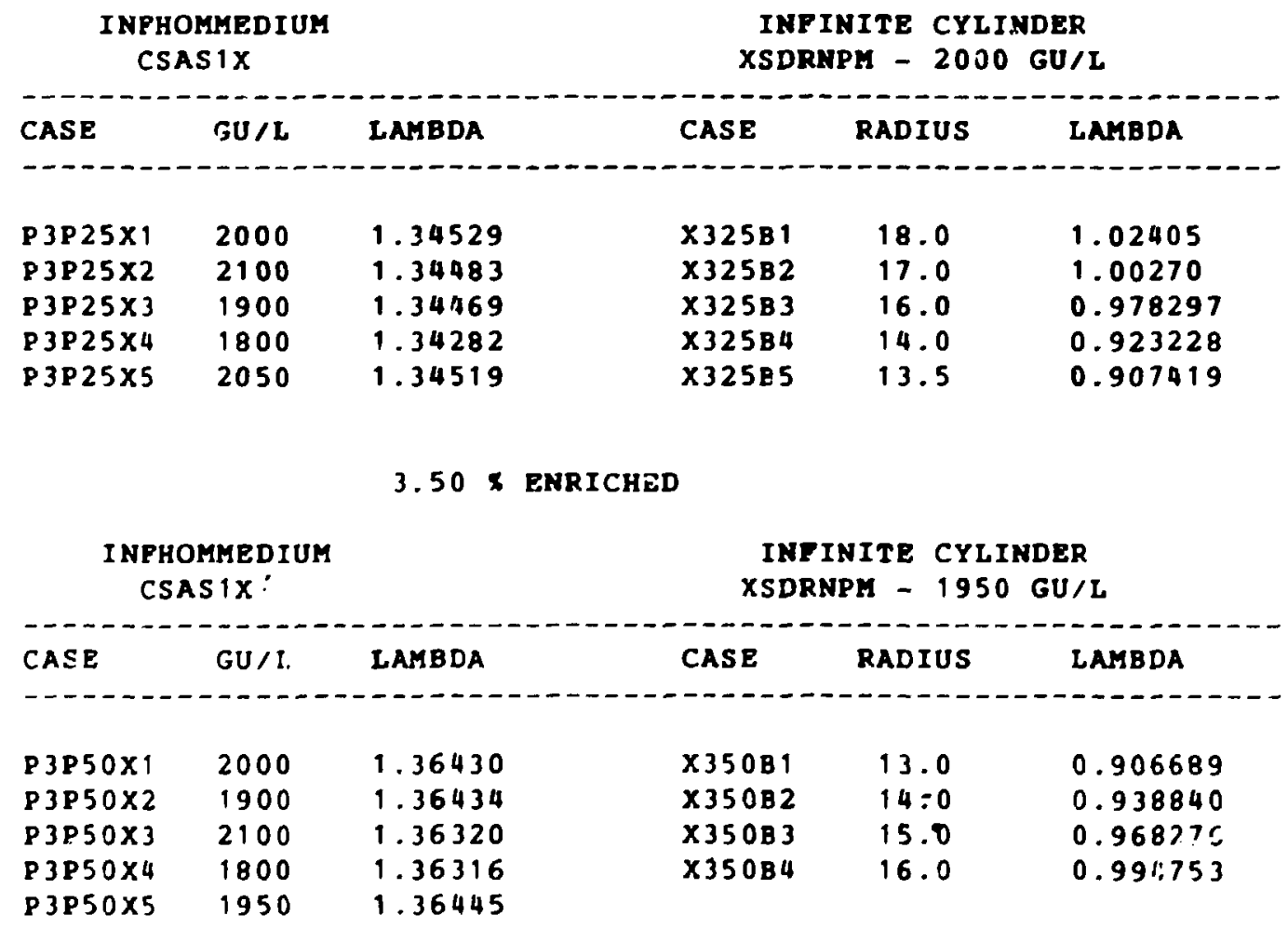


Table A.l (continued)

\section{$3.75 \times$ ENRICHED}

\begin{tabular}{|c|c|c|c|c|c|}
\hline \multicolumn{2}{|c|}{$\begin{array}{l}\text { INPHOMMEDIUM } \\
\text { CSAS IX }\end{array}$} & & $\begin{array}{r}\text { IN } \\
\text { XSD }\end{array}$ & INPINITE CYLINDER & \\
\hline CASE & GU/L & LAMBDA & CASE & RADIUS & LAMBDA \\
\hline P 3P75X1 & 2000 & 1.38120 & X375B1 & 15.5 & 0.997216 \\
\hline P3P75X2 & 1900 & 1.38182 & $\times 375 B 2$ & 14.5 & 0.969079 \\
\hline P 3P75 $\times 3$ & 1800 & 1.38129 & " & $\cdot 3.5$ & 0.937593 \\
\hline P 3P 75X4 & 2100 & 1.37953 & $n$ & 12.5 & 0.903234 \\
\hline P3P75 $\times 5$ & 1975 & 1.38145 & & & \\
\hline & & $4.0 \times$ & & & \\
\hline $\begin{array}{l}\text { INPI } \\
\mathrm{C}\end{array}$ & $\begin{array}{l}\text { MKEDIU } \\
\text { S1X }\end{array}$ & & $\begin{array}{r}\text { IN } \\
\times S D\end{array}$ & $\begin{array}{l}\text { JITE CY } \\
\text { PM } 18\end{array}$ & JR \\
\hline CASE & GU/L & LAMBDA & CASE & RADIUS & LAMEDA \\
\hline $84 \times 1$ & 2000 & 1.39631 & X4B 1 & 12.0 & 0.897497 \\
\hline $84 \times 2$ & 1900 & 1.39748 & X4B2 & 13.0 & 0.934125 \\
\hline P $4 \times 3$ & 1800 & 1.39754 & $\times 483$ & 14.0 & 0.967038 \\
\hline P4X4 & 1850 & 1.39766 & $\times 484$ & 15.0 & 0.996827 \\
\hline P4X5 & 1750 & 1.39712 & & & \\
\hline
\end{tabular}

$4.25 \times$ ENRICHED

\begin{tabular}{|c|c|c|c|c|c|}
\hline \multicolumn{3}{|c|}{$\begin{array}{l}\text { INPHOMMEDIUM } \\
\text { CSAS } 1 X\end{array}$} & \multicolumn{3}{|c|}{$\begin{array}{l}\text { INPINITE CYLINDER } \\
\text { XSDRNPM - } 1800 \mathrm{GU} / \mathrm{I}\end{array}$} \\
\hline CASE & $\mathrm{GU} / \mathrm{L}$ & LAMBDA & CASE & RADIUS & LAMBDA \\
\hline P 4P25X1 & 2000 & 1.40992 & X425B1 & 14.5 & 0.995270 \\
\hline$P 4 \times 25 \times 2$ & 1900 & 1.41160 & $X 425 B 2$ & 13.5 & 0.963371 \\
\hline $94825 \times 3$ & 1800 & 1.41219 & $\times 42583$ & 12.5 & 0.928434 \\
\hline $94225 \times 4$ & 1700 & 1.41158 & " & 11.5 & 0.889422 \\
\hline p4P25 55 & 1825 & 1.41215 & & & \\
\hline
\end{tabular}


Table A.I (continued)

ח.50 I ENRICHED

\begin{tabular}{llllll}
\multicolumn{2}{c}{$\begin{array}{c}\text { INFHOMHEDIUM } \\
\text { CSAS1X }\end{array}$} & \multicolumn{2}{c}{$\begin{array}{c}\text { INFINITE CYLINDER } \\
\text { XSDRNPM }\end{array}$} \\
\hline CASE & GU/L & LANBDA & CASE & RADIUS & LAMBDA \\
\hline & & & & & \\
P4P50X & 2000 & 1.42223 & X450B1 & 11.0 & 0.879445 \\
P4P50X: & 1900 & 1.42437 & $n$ & 12.0 & 0.920530 \\
P4P50X: & 1800 & 1.42546 & X450B2 & 13.0 & 0.957606 \\
P4P50X4 & 1700 & 1.42540 & X450B3 & 14.0 & 0.991094 \\
P4P50X5 & 1750 & 1.42558 & & &
\end{tabular}

$4.75 \times$ ENRICHED

\begin{tabular}{|c|c|c|c|c|c|}
\hline \multicolumn{3}{|c|}{$\begin{array}{l}\text { INFHOMHEDIUM } \\
\text { CSAS IX }\end{array}$} & \multicolumn{3}{|c|}{$\begin{array}{l}\text { INFINITE CYLINDER } \\
\text { XSDRYPY }-1700 \mathrm{GU}\end{array}$} \\
\hline CASE & GU / L & LAMBDA & CASE & RADIUS & LAMBDA \\
\hline P4P75X1 & 2000 & 1.43342 & $\times 47581$ & 13.75 & 0.994239 \\
\hline P4P75:2 & 1900 & 1.43598 & $\times 475 B 2$ & 12.75 & 0.959643 \\
\hline Y4P75X3 & 1800 & 1.43754 & $\times 47583$ & 11.75 & 0.921115 \\
\hline P4P $75 \times 4$ & 1700 & 1.43797 & X475B4 & 11.00 & 0.889450 \\
\hline P4P75X5 & 1650 & 1.43772 & & & \\
\hline & & $5.0 \times$ & & & \\
\hline $\begin{array}{r}\text { INFH } \\
\text { CS }\end{array}$ & $\begin{array}{l}\text { WMEDIU } \\
\$ 1 X\end{array}$ & & $\begin{array}{r}\text { IN } \\
\text { XSD }\end{array}$ & $\begin{array}{l}\text { JITE CYI } \\
\text { M }-167\end{array}$ & $\begin{array}{l}E R \\
U / L\end{array}$ \\
\hline & ch & 30 & con & 20-- & 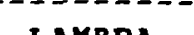 \\
\hline CASP: & GU/L & LAMBDA & CASE & RADIUS & LAMBDA \\
\hline P5X1 & 1900 & 1.44658 & $\times 5 B 1$ & 10.75 & 0.887733 \\
\hline $85 \times 2$ & 1800 & 1.44856 & $\times 582$ & 11.75 & 0.930455 \\
\hline $85 \times 3$ & 1700 & 1.44947 & $\times 5 B 3$ & 12.75 & 0.969052 \\
\hline $85 \times 4$ & 1600 & 1.44912 & $\times 5 B 4$ & 13.75 & 1.00364 \\
\hline P5 $\times 5$ & 1650 & 1.44945 & & & \\
\hline P5XE & 1675 & 1.44950 & & & \\
\hline
\end{tabular}


Table A.I (continued)

\section{$5.25 \times$ ENRICHED}

\begin{tabular}{|c|c|c|c|c|c|}
\hline \multicolumn{2}{|c|}{$\begin{array}{l}\text { INFHOMMED IUM } \\
\text { CSAS } 1 \mathrm{X}\end{array}$} & & \multicolumn{3}{|c|}{ INPINITE CYLINDER } \\
\hline CASE & $\mathbf{G U} / \mathbf{L}$ & LAMBDA & CASE & RADIUS & LAMBDA \\
\hline P5P25X1 & 1800 & 1.45867 & $\times 525 \times 1$ & 13.50 & 1.00491 \\
\hline P5P25×2 & 1700 & 1.46002 & $\times 525 \times 2$ & 12.50 & 0.969062 \\
\hline P5P25 $\times 3$ & 1600 & 1.46014 & $\times 525 \times 3$ & 11.50 & 0.929092 \\
\hline P5P25 44 & 1650 & 1.46023 & $\times 525 \times 4$ & 10.75 & 0.896336 \\
\hline P5P25X5 & 1550 & 1.45969 & & & \\
\hline & & $5.50 \times$ & & & \\
\hline $\begin{array}{l}\text { INFI } \\
\quad C:\end{array}$ & $\begin{array}{l}\text { AMEDTU } \\
51 x\end{array}$ & & $\begin{array}{r}\text { INI } \\
\text { XSDI }\end{array}$ & $\begin{array}{l}\text { NITE CY } \\
\text { PM - } 16\end{array}$ & $\begin{array}{l}E R \\
U / L\end{array}$ \\
\hline CASE & GU/L & LAMBDA & CASE & RADIUS & LAMBDA \\
\hline P5P50X1 & 1750 & 1.46900 & $\times 550 \times 1$ & 10.50 & 0.892905 \\
\hline P5P50X2 & 1700 & 1.46973 & $\times .550 \times 2$ & 11.25 & 0.926734 \\
\hline P5P50 53 & 1650 & 1.47016 & $\times 550 \times 3$ & 12.25 & 0.967752 \\
\hline P5P50X4 & 1600 & 1.47029 & $\times 550 \times 4$ & 13.25 & 1.00465 \\
\hline P5P50X5 & 1550 & 1.47007 & & & \\
\hline
\end{tabular}




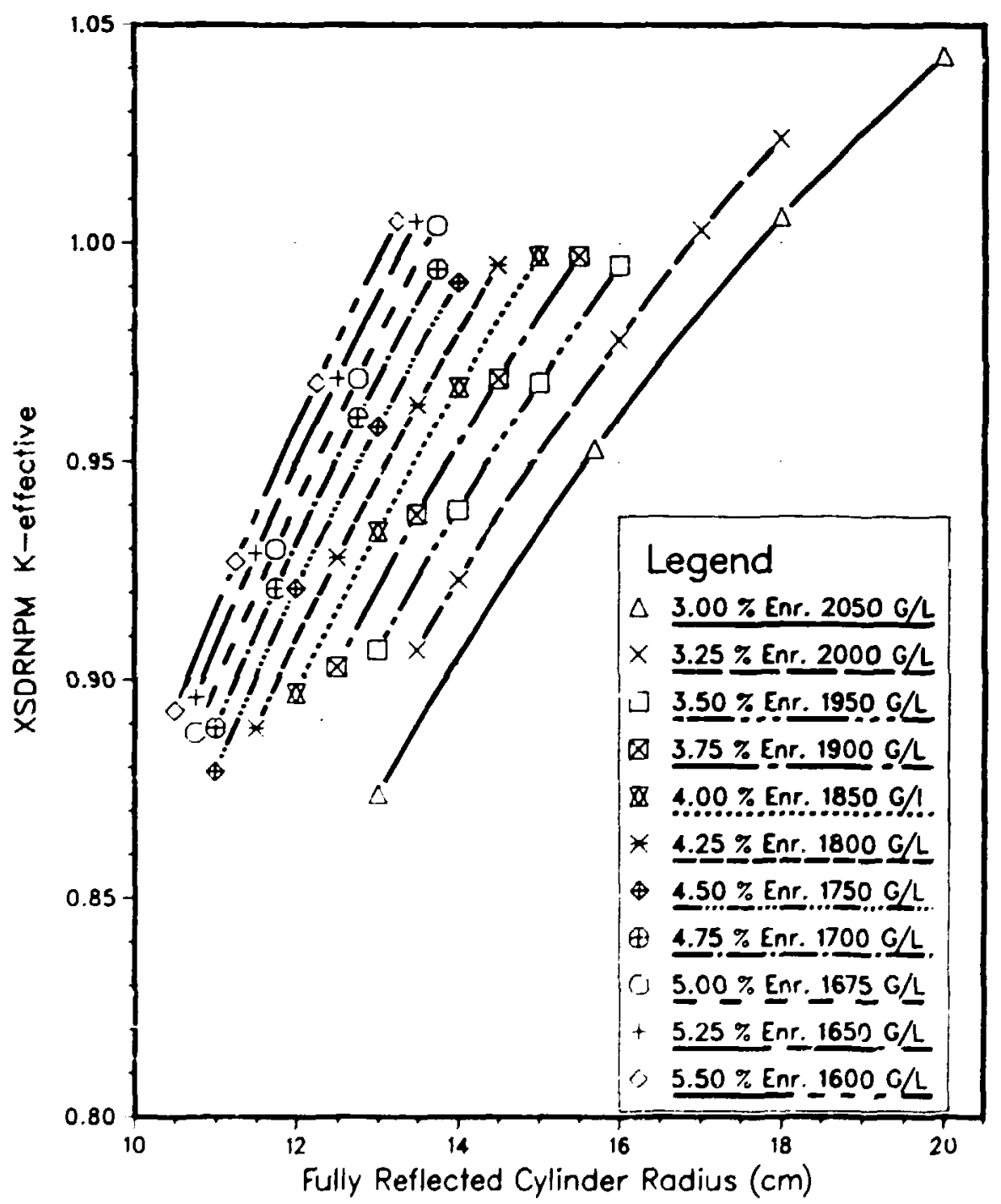

Fig. A.1 Paducah $\mathrm{UO}_{2} \mathrm{~F}_{2}$. Solution Cylinders 


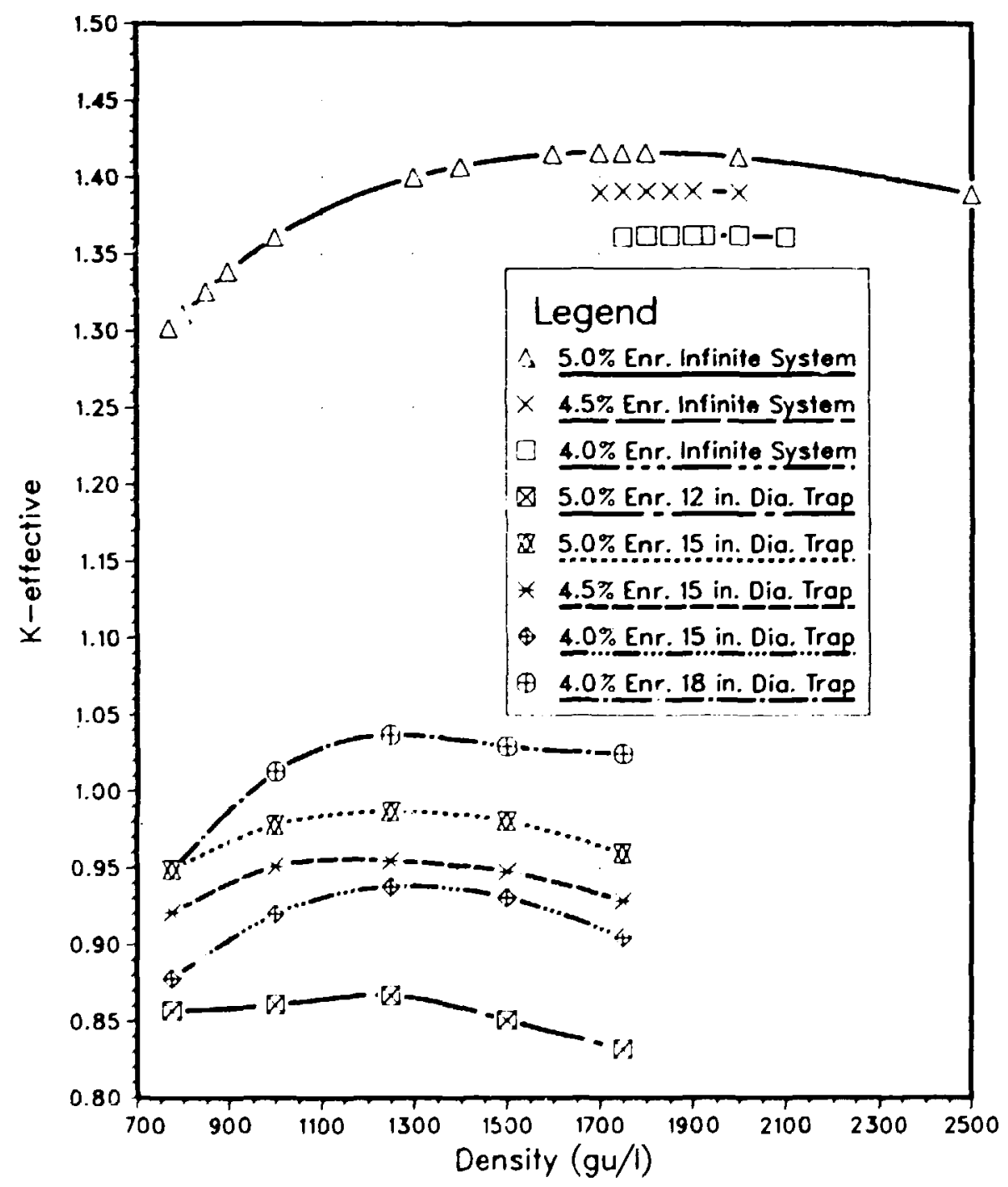

Fig. A.2 $\mathrm{UO}_{2} \mathrm{~F}_{2}$ in $\mathrm{AL}_{2} \mathrm{O}_{3}$ Traps (Fully Reflected) 


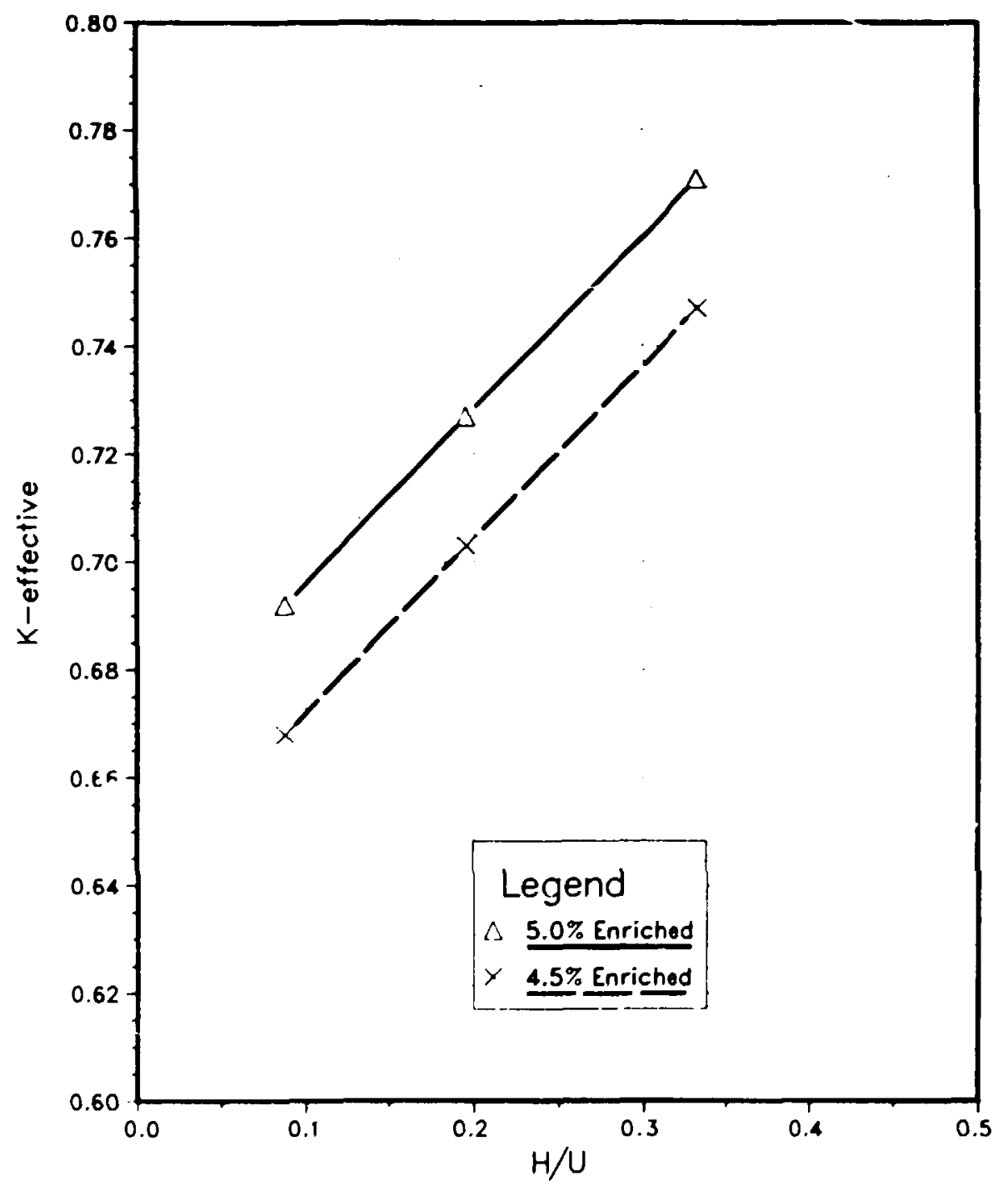

Fig. A.3 Product Accumulators (Fully Reflected) $4.5 \%$ vs $5.0 \%$. 


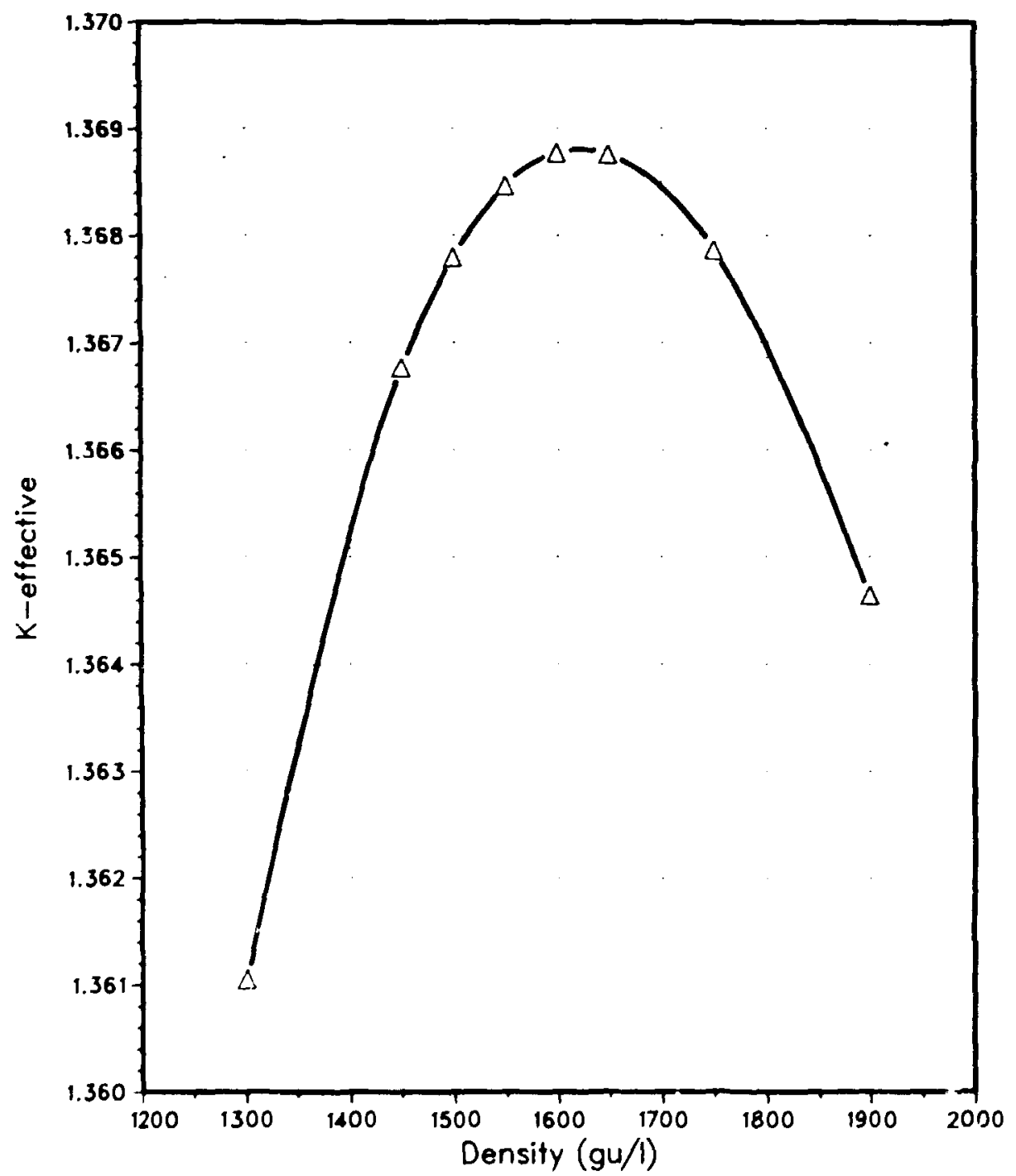

Fig. A.4 Optimum U Concentration for NaF Burp Traps 


\section{INTERNAL DISTRIBUTION}

$\begin{array}{ll}\text { 1. } & \text { R. C. Baker } \\ 2 . & \text { C. R. Beverly } \\ 3 . & \text { J. T. Bradbury } \\ \text { 4. } & \text { J. M. Collins } \\ 5 . & \text { D. G. Cope/C. G. Giltner } \\ \text { 6. } & \text { K. A. Davis } \\ 7 . & \text { J. E. Dew } \\ 8 . & \text { R. G. Donnelly } \\ 9 . & \text { H. R. Dyer } \\ 10 . & \text { W. R. Golliher } \\ 11-12 . & \text { O. W. Hermann } \\ 13 . & \text { T. M. Hines } \\ 14 . & \text { C. C. Hopkins } \\ 15 . & \text { R. P. James } \\ 16 . & \text { T. A. Jokerst } \\ 17 . & \text { R. P. Leinius/X-10 CS Library } \\ 18 . & \text { T. R. Lemons } \\ 19 . & \text { D. C. Mason } \\ 20 . & \text { W. T. Mee } \\ 21 . & \text { J. R. Merriman } \\ 22-24 . & \text { L. M. Petrie } \\ 25 . & \text { H. Pulley }\end{array}$

$\begin{array}{ll}\text { 26. } & \text { J. E. Rushton } \\ 27 . & \text { J. E. Shoemaker } \\ 28-30 . & \text { G. B. Stewart } \\ 31 . & \text { W. E. Sykes } \\ 32 . & \text { R. G. Taylor } \\ 33 . & \text { J. H. Thomas } \\ 34 . & \text { J. T. Thomas } \\ 35 . & \text { W. E. Thompson } \\ 36 . & \text { J. C. Turner } \\ 37 . & \text { R. R. Veazey } \\ 38 . & \text { C. W. Walter } \\ 39 . & \text { R. M. Westfall } \\ 40 . & \text { G. E. Whitesides } \\ 41 . & \text { Central Research Library } \\ 42 . & \text { Document Reference Section Y-12 } \\ 43-44 . & \text { Laboratory Records } \\ 45 . & \text { Laboratory Records - RC } \\ 46 . & \text { ORNL Patent Section } \\ 47 . & \text { K-25 CS Library } \\ 48-50 . & \text { K-25 Plant Library } \\ & \\ & \end{array}$

\section{EXTERNAL DISTRIBUTION}

51. J. N. Rogers, Div. 8324, Sandia Laboratories, Livermore, CA 94550

52. Division of Engineering, Mathematics and Geosciences, DOE, Washington, DC 20545

53. Office of Assistant Mgr. for Energy Research and Development. DOE/ORO, Oak Ridge, TN 37830

54-56. H. D. Fletcher, U.S. Department of Energy, Washington, DC 20545

57. W. A. Pryor, DOE/ORO, Oak Ridge, TN 37830

58-94. Technical Information Center, Oak Ridge, TN 37830 